\title{
Analysis of gas condensate and its different fractions of Bibiyana gas field to produce valuable products
}

\author{
S. M. A. Sujan ${ }^{1 *}$, M. S. Jamal ${ }^{1}$, M. Hossain ${ }^{1}$, M. Khanam ${ }^{1}$ and M. Ismail ${ }^{2}$ \\ ${ }^{1}$ Institute of Fuel Research and Development, Bangladesh Council of Scientific and Industrial Research, \\ Dr.Qudrat-I-Khuda Road, Dhaka-1205, Bangladesh \\ ${ }^{2}$ Dept. of Applied Chemistry \& Chemical Engineering, University of Dhaka, Dhaka-1000, Bangladesh
}

\begin{abstract}
Physicochemical characteristics of raw gas condensate from Bibiyana gas field, commercial motor spirit, kerosene and diesel fuel as well as products obtained from gas condensate were determined. Experiments were carried out to take apart motor spirit, kerosene and diesel from gas condensate based on boiling ranges. The analysis revealed that collected gas condensate contains more than $50 \%$ is motor spirit (regular octane/petrol) in the boiling range of $21-145^{\circ} \mathrm{C}, 23 \%$ is kerosene in the boiling range of $140-221^{\circ} \mathrm{C}$ and $24-25 \%$ is diesel in the boiling range of $178-335^{\circ} \mathrm{C}$. Remaining $2-3 \%$ is found as residue and system loss. The characteristics of different fractions (Motor spirit, Kerosene \& Diesel) obtained from condensate are very comparable to commercial products (collected from nearby fuel pump station supplied by Meghna petroleum) and BSTI standard except two properties of petrol (octane number and sulfur content). The octane number of motor spirit is increased by adding $5 \%$ of supper octane or ethanol or MTBE.
\end{abstract}

Key words: Bibiyana gas field; Gas condensate; Boiling range; BSTI; Motor spirit (Petrol); Kerosene; Diesel; MTBE \& Super octane

\section{Introduction}

Condensate is a low density, high API gravity colorless or light yellow liquid hydrocarbons which is generally found with natural gas. Internal temperature and pressure of the reservoir allows it to be in liquid form. The natural gas condensate is also referred to as simply condensate or gas condensate or sometimes natural gasoline, because it contains hydrocarbons within the gasoline boiling range.

There are hundreds of wet gas field worldwide and each has its own unique gas condensate composition. Natural gas condensate is typically composed of hydrocarbons ranging from $\mathrm{C}_{4}$ to $\mathrm{C}_{15}$ in which mainly contain $25-95 \%$ by wt of $\mathrm{C}_{6}, \mathrm{C}_{7}$ and $\mathrm{C}_{8}$ organic compounds. In natural gas condensate comprises hexane, cyclohexane and benzene as $\mathrm{C}_{6}$ hydrocarbon; heptane and toluene as $\mathrm{C}_{7}$ hydrocarbon where as octane, ethyl benzene and xylenes consider as $\mathrm{C}_{8}$ hydrocarbon. Natural gas condensate also has minor amount of $\mathrm{C}_{5}(5-7 \%$ by $\mathrm{wt})$ as pentane and other hydrocarbons up to $\mathrm{C}_{15}$. Beside these gas condensate has trace amount of hydrogen sulfide $\left(\mathrm{H}_{2} \mathrm{~S}\right)$, carbon dioxide $\left(\mathrm{CO}_{2}\right)$, mercaptanes ( $\left.\mathrm{RSH}, \mathrm{R}=-\mathrm{CH}_{3},-\mathrm{C}_{2} \mathrm{H}_{5}\right)$ and aromatics. (http://en.wikipedia.org/wiki/Natural_gas_condensate).
In recent year researchers are trying to findout the way to utilize all raw materials from which energy can be obtained. The present situation of gas condensate in Bangladesh is about 99,000 to $1,00,000$ tons and the total production of gas condensate in different gas fields is up to 6605.2 BBLD in Bangladesh (Date: 23-24/10/2013) (http://www.petrobangla. org.bd). This condensate can be used to produce varieties of useful products by refining. New refining plants are being established in recent year. So the demand of condensate refining is increasing gradually (Begum et al. 2010).

Now a days, condensate which is obtained from Sangu and Kailastila Gas fields, is mainly processed by Eastern Refinery Limited (ERL). The authority of Eastern Refinery Limited (ERL) mixed the condensate with crude oil and processed it. About 97.5 - $98 \%$ petrol / naptha is obtained from the condensate and $2-2.5 \%$ is found as operation loss. Bibiyana gas field located at Nabigonj of Hobigonj district was discovered in July, 1998. This is the second largest gas field so far discovered in Bangladesh, both in terms of quality and size of the reserve (Saha 2012). The total reserve of gas has been estimated about

\footnotetext{
*Corresponding author: asad2306@gmail.com
} 
5.5 TCF (Trillion cubic feet) and 30.7 million barrels of condensate. At present it produces more than 750 MMSCFD of natural gas and approximately 3,500 BPD of condensate which is reserved into 6 condensate storage tanks of Bibiyana gas field (Saha 2012). With a view to produce valuable products such as about $50 \%$ motor spirit (Regular octane), 25\% kerosene and 25\% diesel from the condensate of Bibiyana gas field was collected and conducted details experiments. Characterization and up-gradation of the products were done to satisfy the level of BSTI standard (Anonimous, 2009).

\section{Materials and methods}

\section{Materials}

Gas condensates were collected from Bibiyana gas field, Hobigonj. Commercial petrol, kerosene, diesel, motor spirit (100\% octane) and MTBE were collected from local market. The chemicals used in this research work were reagent grade.

\section{Method}

Properties of gas condensate, commercial motor spirit, kerosene and diesel fuel and products obtained from gas condensate were determined by standard methods.

The octane number of the motor spirit fraction and commercial petrol has been determined through gasoline analyzer (D 2700). Cetane number of the diesel fraction and commercial diesel has been determined through diesel fuel analyzer (D 613-86).

Sulphur content of condensate, motor spirit, kerosene, diesel fraction and commercial motor spirit, diesel and kerosene was determined by standard method D 129-64.

Other properties such as density (D 1298), viscosity (D 445-65), flash point (D 93-62), smoke point (D 1322-64), aniline Point (D 611-64), carbon residue (D 189-65), color (D 1500-64), corrosion (D 130-65), residue on evaporation (IP-131/58), API gravity (D 287-64), acid value (IP-1/58), ash content (D 482-63), water content (IP-74/57), pour point (D 97-57) etc have been determined by standard methods.

The metallic substances present in the gas condensate such as lead, arsenic, zinc, cadmium have been determined by Atomic absorption spectrophotometer (D 1269-61 \& D 1549-64).

\section{Fractionation of gas condensed}

Gas condensate has been distilled and fractionated into motor spirit, diesel and kerosene fractions using atmospheric vacuum distillation apparatus (ASTM-1160).

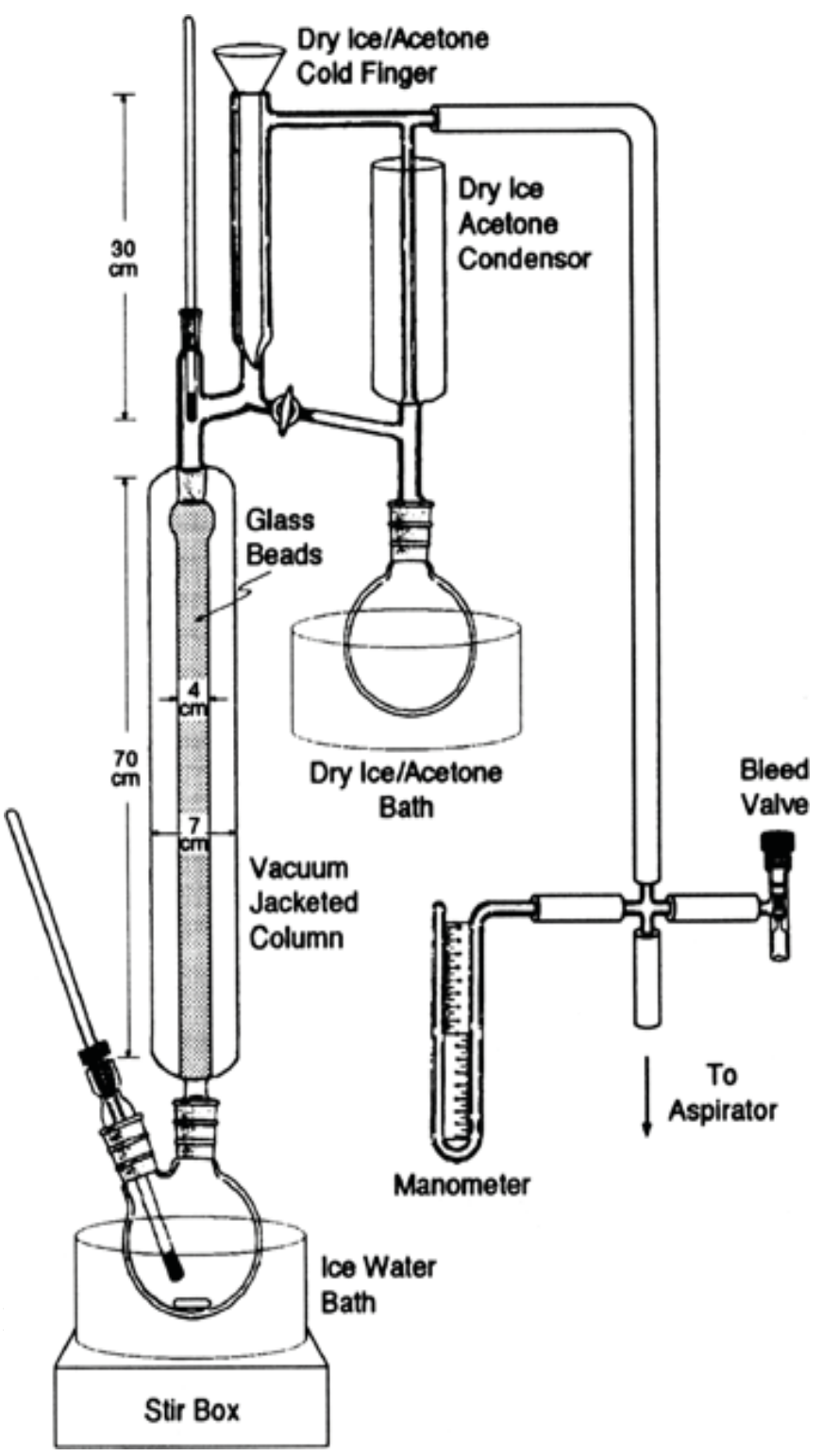

Fig. 1. Flow diagram of fractionation unit.

\section{Results and discussion}

Properties of gas condensate which is collected from Bibiyana gas field are shown in the Table I. The fractionation of gas condensate based on boiling range shown in the Table II. 
Table I. Properties of gas condensate collected from Bibiyana gas field

\begin{tabular}{|c|c|c|}
\hline Name of the analysis & Method & Results \\
\hline Range of boiling point, ${ }^{0} \mathrm{C}$ & D 1160 & $21-345$ \\
\hline Motor Spirit & & 50 \\
\hline Kerosene & & 23 \\
\hline Diesel & & 24 \\
\hline Density at $15^{\circ} \mathrm{C}, \mathrm{Kg} / \mathrm{L}$ & D 1298 & 0.8184 \\
\hline API gravity, $60 / 60^{\circ} \mathrm{F}$ & D $287-64$ & 43 \\
\hline Kinematic Viscosity, $c$ St $122{ }^{0} \mathrm{~F}$ & D $445-65$ & 0.999 \\
\hline Kinematic Viscosity, $c$ St $70^{\circ} \mathrm{F}$ & D $445-65$ & 1.43 \\
\hline Pour Point, ${ }^{0} \mathrm{C}$ & D $97-57$ & Below -20 \\
\hline Aniline Point, ${ }^{0} \mathrm{C}$ & D 611-64 & 43 \\
\hline Acid Value, mg KOH/g & IP-1/58 & 0.077 \\
\hline Flash Point, ${ }^{0} \mathrm{C}$ & D 93-62 & 22 \\
\hline Sulfur content, mass $\%$ & D $129-64$ & 0.245 \\
\hline Water content, $\%$ & IP-74/57 & Zero \\
\hline Light hydrocarbon (Below $50^{\circ} \mathrm{C}$ ), \% & D 1160 & 4.0 \\
\hline Carbon residue, $\%$ & D $189-65$ & 1.50 \\
\hline Ash content, \% & D $482-63$ & 0.0075 \\
\hline Residue on evaporation, $\%$ & IP-131/58 & 0.387 \\
\hline Lead & D $1269-61$ & 0.07845 \\
\hline Arsenic & - & 0.00625 \\
\hline Zinc & D 1549-64 & 0.78812 \\
\hline Cadmium & - & 0.00013 \\
\hline
\end{tabular}

Table II. Distillation products by atmospheric vacuum distillation unit (method D1160) of gas condensate collected from Bibiyana gas field based on temperature ranges

\begin{tabular}{cc}
\hline Amount(vol \%) & Temperature $^{\mathbf{0}} \mathbf{C}$ ) \\
\hline Initial boiling point & 21 \\
$10 \%$ & 85 \\
$20 \%$ & 96 \\
$30 \%$ & 104 \\
$40 \%$ & 118 \\
$50 \%$ & 142 \\
$60 \%$ & 162 \\
$70 \%$ & 190 \\
$80 \%$ & 222 \\
$90 \%$ & 286 \\
$95 \%$ & 342 \\
Besides this Residue\% & 2 \\
Loss $\%$ & 3 \\
\hline
\end{tabular}

Condensate of Bibiyana gas field was fractionated into 3 major parts based on boiling range by using atmospheric vacuum distillation apparatus. First part motor spirit/Petrol (PFC) was collected in the boiling range $21^{\circ} \mathrm{C}-145^{\circ} \mathrm{C}$ and it is known as regular motor spirit /petrol. It was found that major properties of PFC such as density, viscosity and flash point were almost identical with commercial petrol which was analyzed in hydrocarbon section in IFRD (collected from nearby fuel pump station supplied by Meghna petroleum) and BSTI standard except octane rating which is shown in Table III.

Octane number can be increased by adding antiknock additives and octane- increasing compounds to the motor spirit/petrol fraction of condensate to increase the octane number which is the simplest and most reasonable from in the technological point of view (Stepanov 2005). For improving the octane number of motor spirit (regular octane) fraction, 5\% of different improvers or additives are blended with motor spirit as 
shown in Table IV. Among the five different improvers super octane and ethanol showed the most promising result.

Second fractionated product which is known as kerosene fraction (KFC) in boiling ranges $221^{\circ} \mathrm{C}$. The properties of KFC were compared with commercial kerosene which was analyzed in hydrocarbon section in IFRD (collected from nearby fuel pump station supplied by Meghna petroleum) and BSTI standard. It was found that major properties of KFC such as density, viscosity and flash point were almost identical with commercial kerosene which is shown in Table V. The major advantage of $\mathrm{KFC}$ in respect to environment was low sulfur content in compare with commercial kerosene.

Third fractionated product known as diesel fraction (DFC) was collected in the boiling range $178^{\circ} \mathrm{C}-335^{\circ} \mathrm{C}$.

Table III. Comparison of different properties of motor spirit (Petrol) with commercial Petrol and BSTI Standard (June 2009)

\begin{tabular}{|c|c|c|c|c|}
\hline Name of the analysis & Method & $\begin{array}{l}\text { Petrol fraction } \\
\text { from condensate }\end{array}$ & $\begin{array}{l}\text { Commercial } \\
\text { Petrol }\end{array}$ & $\begin{array}{l}\text { BSTI Standard } \\
\text { (June 2009): } \\
\text { BDS 347:1999 }\end{array}$ \\
\hline Range of boiling, ${ }^{0} \mathrm{C}$ & D 1160 & $21-145$ & $19.8-196$ & - \\
\hline Mass \% & , & 49 & - & - \\
\hline Volume \% & , & 50 & - & - \\
\hline Density at $15^{\circ} \mathrm{C}, \mathrm{Kg} / \mathrm{L}$ & IP-160/57 & 0.7516 & 0.7423 & - \\
\hline API gravity, $60 / 60^{\circ} \mathrm{F}$ & D $287-64$ & 50 & - & - \\
\hline Distillation Range IBP & D 1160 & 21.5 & 19.8 & Not limited \\
\hline $10 \%$ & , & 65 & 53 & 75 \\
\hline $50 \%$ & , & 110 & 74 & $80-125$ \\
\hline $90 \%$ & , & 139 & 160 & 180 \\
\hline FBP & 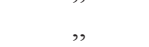 & 145 & 196 & 210 \\
\hline Acid value, mg KOH/g & IP-1/58 & 0.0798 & 0.09 & - \\
\hline Water content, $\%$ & IP-74/57 & Zero & Zero & - \\
\hline Color (ASTM) & D $1500-64$ & Zero & 0.5 & Visual \\
\hline Flash point, ${ }^{0} \mathrm{C}$ & D 93-62 & 17 & 13.33 & - \\
\hline Kinematic Viscosity, $70^{\circ} \mathrm{F} c S t$ & D $445-65$ & 0.615 & 0.5253 & Not limited \\
\hline Grade of corrosion & D $130-65$ & Zero & Zero & No worse than no.1 \\
\hline Sulfur content, mass $\%$ & D $129-64$ & 0.1553 & 0.455 & 0.05 \\
\hline Naphthene & - & 10.7 & 4.5 & - \\
\hline Aromatics & D 1320 & 43.8 & 31.9 & - \\
\hline Motor test & D 2700 & 73 & 77 & - \\
\hline Research method & D 2699 & 78 & 83 & 80 \\
\hline Residue on evaporation, wt \% & IP-131/58 & 0.0084 & 0.023 & $4 \mathrm{mg} / 100 \mathrm{ml}$ \\
\hline Reid steam pressure at $38^{\circ} \mathrm{C}$, psi & & 8.5 & - & 10 \\
\hline Doctor test & & Negative & - & Negative \\
\hline Lead content, $\mathrm{mg} / \mathrm{kg}$ & & 0.041 & - & $0.013 \mathrm{~g} / \mathrm{L}$ \\
\hline
\end{tabular}

Table IV. Improvement of octane number by using different types of improver

\begin{tabular}{lc}
\hline Name of the improving additives & $\begin{array}{c}\text { Increased octane number } \\
\text { (Research method D 2699) }\end{array}$ \\
\hline Methyl tert. Butyl Ether (MTBE) & 80 \\
Hydrogen Peroxide & 79 \\
Ethanol & 81 \\
Normal Octane & 80 \\
Super Octane (100 Octane) & 81 \\
\hline
\end{tabular}

The properties of DFC were compared with commercial diesel which was analyzed in hydrocarbon section in IFRD (collected from nearby fuel pump station supplied by Meghna petroleum) and BSTI standard. It was found that flash point and cetane number of DFC are higher in compare with commercial diesel which is shown in Table VI. 
Table V. Comparison of different properties of KFC with commercial kerosene and BSTI Standard (June 2009).

\begin{tabular}{|c|c|c|c|c|c|}
\hline \multirow{2}{*}{ Name of the test } & \multirow{2}{*}{ Method } & \multirow{2}{*}{$\begin{array}{c}\text { Kerosene } \\
\text { fraction } \\
\text { from } \\
\text { condensate }\end{array}$} & \multirow{2}{*}{$\begin{array}{l}\text { Commercial } \\
\text { Kerosene }\end{array}$} & \multicolumn{2}{|c|}{$\begin{array}{l}\text { BSTI Standard (June } \\
\text { 2009): BDS 830:1991 }\end{array}$} \\
\hline & & & & Grade 1 & Grade 2 \\
\hline Range of boiling, ${ }^{\circ} \mathrm{C}$ & D 1160 & $140-221$ & $43.5-228$ & - & - \\
\hline Mass $\%$ & , & 23 & - & - & - \\
\hline Volume \% & ", & 23 & - & - & - \\
\hline Density at $15^{\circ} \mathrm{C}, \mathrm{Kg} / \mathrm{L}$ & IP-160/57 & 0.7882 & 0.7956 & Not limited & Not limited \\
\hline API gravity, $60 / 60^{\circ} \mathrm{F}$ & D 287-64 & 38 & - & - & - \\
\hline IBP & D 1160 & 51 & 43.5 & - & - \\
\hline Distillation & ", & 165 & 148 & - & - \\
\hline Range & ", & 207 & 174 & - & - \\
\hline Range & ", & 215 & 219 & - & - \\
\hline FBP & ", & 221 & 228 & - & - \\
\hline $\begin{array}{l}\text { Kinematic Viscosity at } \\
70^{\circ} \mathrm{F}, c S t\end{array}$ & D 445-65 & 1.758 & 1.728 & - & - \\
\hline Pour Point, ${ }^{\circ} \mathrm{C}$ & D $97-57$ & Below -20 & Below -20 & - & - \\
\hline Acid value, mg $\mathrm{KOH} / \mathrm{g}$ & IP-1/58 & 0.126 & 0.078 & - & - \\
\hline Flash point,${ }^{\circ} \mathrm{C}$ & D 93-62 & 45 & 47 & 35 & 43 \\
\hline Grade of corrosion & D $130-65$ & Slight & Zero & $\begin{array}{l}\text { Not worse } \\
\text { than no } 1\end{array}$ & $\begin{array}{l}\text { Not worse } \\
\text { than no } 2\end{array}$ \\
\hline Sulfur content, mass $\%$ & D $129-64$ & 0.2253 & 0.597 & 0.40 & 1.0 \\
\hline Aromatics content, $\%$ & D 1320 & 47.5 & 45 & - & - \\
\hline Smoke point, $\mathrm{mm}$ & D $1322-64$ & 16 & 14 & 20 & 10 \\
\hline Color, (ASTM) & D1500-64 & Zero & Blue visual & 10 & - \\
\hline Residue on evaporation, wt \% & IP-131/58 & 0.243 & 0.723 & - & - \\
\hline Ash content, $\%$ & D $482-63$ & 0.015 & - & - & - \\
\hline Doctor test & IP-30/56 & Negative & - & - & Negative \\
\hline
\end{tabular}

Table VI. Comparison of different properties of fractionated diesel from Bibiyana gas field condensate and commercial diesel with BSTI Standard (June 2009).

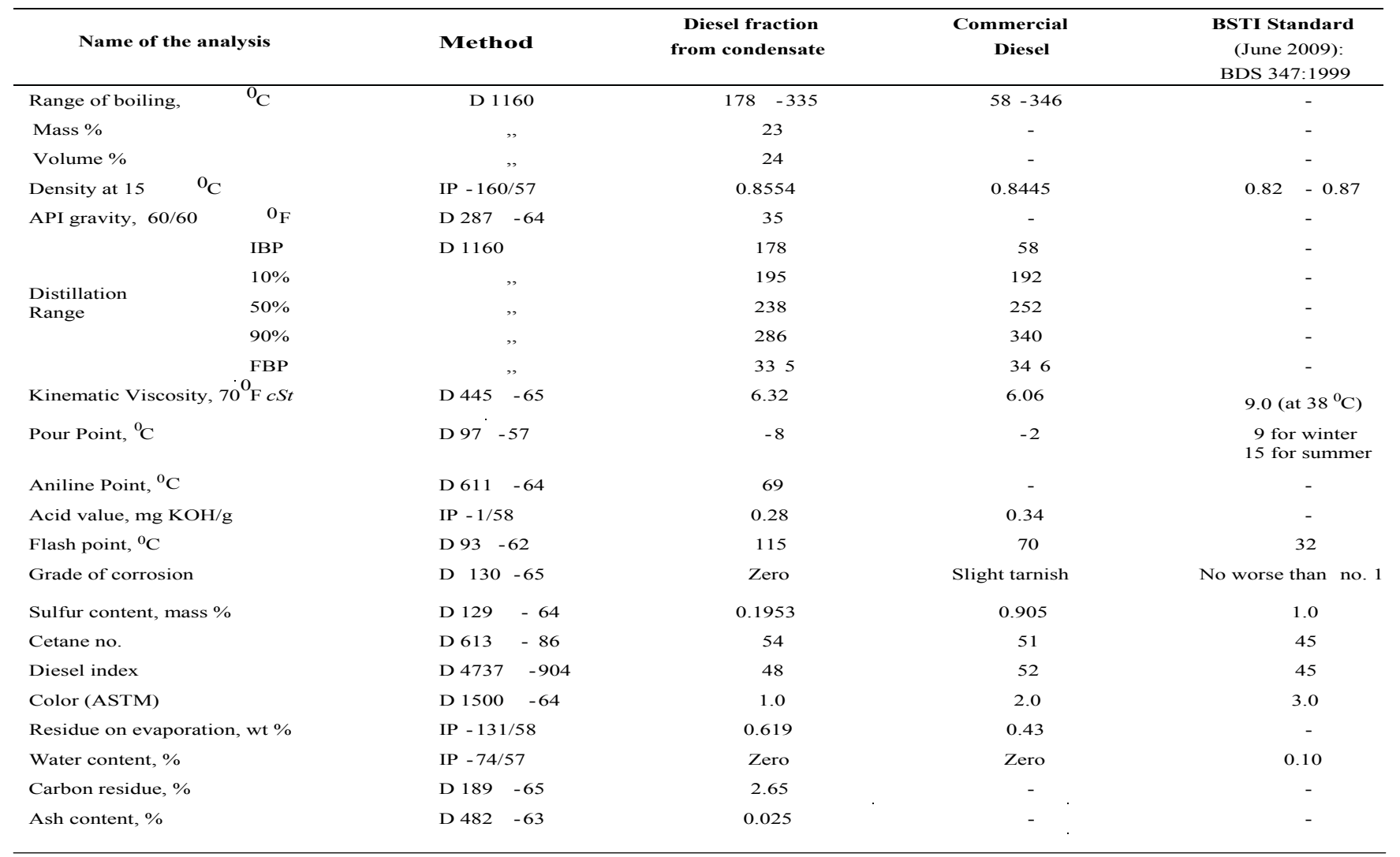




\section{Conclusion}

Natural gas condensate is composed of different types of hydrocarbons. The experiments exposed that $50 \%$ motor spirit (regular octane/petrol) was produced in the boiling range of $21-145^{\circ} \mathrm{C}, 23 \%$ kerosene of $140-221^{\circ} \mathrm{C}$ and $24-25 \%$ diesel of $178-335^{\circ} \mathrm{C}$ from Bibiyana gas condensate. The characteristics of produced motor spirit fraction are close to commercial motor spirit (available in the market) as well as BSTI standard except octane number (78) and sulfur content $(0.1553 \%)$. The sulphur contents in kerosene $(0.2253 \%)$ and diesel fractions $(0.1953 \%)$ are found to be much lower than the commercial kerosene and diesel and even than BSTI standard up to June 2009. The properties of diesel fractions obtained from condensate are very comparable to commercial diesel (available in the market) and BSTI standard. Improvement of octane number (81) of motor spirit fraction has been done by adding five different improvers. It was found that $5 \%$ of supper octane or ethanol showed the best result.

\section{Nomenclature}

BBLD Barrels per Day

BSTI Bangladesh Standard Testing Institute

BTU British Thermal Unit

MSCFD Thousand Standard Cubic Feet per Day

MMSCFD Million Standard Cubic Feet per Day

MTBE Methyl tert. Butyl Ether

\section{Acknowledgement}

Foremost, we would like to express our sincere gratitude to authority of China Petrochemical International Co. Ltd for their continuous support and give us financial support for carrying out this research work. Besides this, we would like to thank laboratory technicians K. M. Abul Kalam, Md. Nasu Miah and Md. Abdul Hamid for their sincere assistance.

\section{References}

Anonymous, BSTI Standard (June 2009): BDS 830:1991

Anonymous, BSTI Standard (June 2009): BDS 347: 1999 http://en.wikipedia.org/wiki/Natural_gas_condensate http://www.petrobangla.org.bd.
Begum DA, Rahman A and Kirtania K (2010), Condensate Fractionation Column: Design variation study by simulation, Journal of Chemical Engineering, IEB; Vol. ChE, 25 (1): 65-70.

Saha PK and Rahman M (2012), Vapor Recovery from Condensate Storage Tanks Using Gas Ejector, Technology Journal of Chemical Engineering, IEB; Vol. ChE, 27 (1): 37-41.

Stepanov VG and Ione KG (2005), Petrol Production from Virgin Fraction of oil and Gas

Condensates with the use of Zeoforming Process, Chemistry for Sustainable Development 13: 805-818.

Standard Methods: D 1160, D 1298, D 287-64, D 445-65, D 97-57, D 611-64, IP-1/58, D 93-62, D 129-64, IP-74/57, D 1160, D 189-65, D 482-63, IP-131/58, D 1269-61, D 1549-64, IP-160/57, D 130-65, D 1320, D 1322-64, D1500-64, IP-30/56.

Received: 27 Novermber 2013; Revised: 19 March 2015

Accepted: 24 March 2015. 